\title{
ANALISA DAN PERANCANGAN SISTEM INFORMASI SEKOLAH BERBASIS WEB DI SMA 2 KOTA SERANG
}

\author{
Benny Suhendar \\ Universitas Banten Jaya \\ Kota Serang, Banten \\ email:bennysuhendar@unbaja.ac.id
}

\begin{abstract}
This research entitled "Web Based Information Sistem at Serang High School (Senior High School) of Serang Regency for the data processing of school in Serang Regency/City through Education Office This sistem is designed using UML Modeling, while programming language used is PHP and MYSQL database. The result of this design is the information sistem application that presents information owned by each Secondary School in Serang Regency/City so that prospective students, parents, and community can find the school information through Education Office of Serang Regency / City
\end{abstract}

Keywords:Information Sistems, Web, SMA

\section{PENDAHULUAN}

Pendidikan sangatlah penting untuk masa depan putra-putri kita, sehingga biasanya kita menginginkan putra-putri kita sekolah ditempat yang mempunyai kualitas pendidikan yang baik. Tetapi sekarang ini sebagai orang tua, kadang kita kesulitan mencari sekolah yang baik untuk putra-putri kita.

Banyak orang tua siswa yang bingung dalam menentukan sekolah mana yang baik untuk putra-putrinya, hal itu sering kali dikarenakan informasi yang kurang tentang sekolah-sekolah yang ada. Untuk itu diperlukan suatu informasi tentang sekolah yang ada baik ditingkat Kabupaten atau Kota mulai dari profil, lokasi sekolah, sarana dan prasaraana yang tersedia, kegiatan, pengajar dan prestasi sekolah serta semua hal yang dapat memberikan sedikit gambaran tentang suatu sekolahan.

Hal itu diharapkan dapat membantu orang tua siswa dalam menentukan sekolah mana yang sesuai dengan putra-putrinya. Pada penelitian ini mencoba untuk merancang suatu Analisa dan Perancangan Sistem Informasi Sekolah di Kabupatenatau Kota yang berbasis web. 
Analisa Perancangan Sistem Informasi Sekolah di Kabupaten atau Kota berbasis web adalah bentuk pengembangan sistem informasi berbasis teknologi informasi. Dari hasil Analisa dan Perancangan Analisa serta Perancangan Sistem Informasi Sekolah di Kabupaten atau Kota Berbasis Web ini dikembangkan kebentuk suatu sistem yang dapat menyampaikan informasi sekolah di Kabupaten atau Kota untuk membantu orang tua siswa dalam menentukan sekolah yang sesuai dengan putra-putri mereka.

Dari uraian di atas maka dapat diambil suatu perumusan masalah sebagai berikut: Bagaimana menganalisa dan merancang suatu Sistem Informasi Sekolah di Kabupaten atau Kota yang Berbasis Web sehingga para orang tua siswa mempunyai gambaran yang baik dan benar tetang sekolah mana yang sesuai dengan harapan dan keinginan orang tua untuk putra-putri mereka.

Dari latar belakang dan perumusan masalah di atas agar pembahasan masalah tidak menyimpang dari pokok permasalahan, maka peneliti membatasi pembahasan masalah ini pada:

\section{a. Analisa dan desain}

Secara konseptual sistem informasi sekolah di Kabupaten atau Kota yang berbasis web khususnya untuk sekolah menengah Atas. Proses analisa dan desain secara konseptual dengan cara pengumpulan data jenis produk yang dijual, media dan ala tpemasaran yang selama ini dilaksanakan serta daerah pemasarannya. Hal ini digunakan untuk keperluan analisis kebutuhan dan desain sistem informasi penjualan online yang akan diterapkan.

\section{b. Perancangan prototype}

Sistem informasi sekolah di Kabupaten atau Kota Serang berbasis web dikhususkan ke sekolah menengah atas. Proses perancangan prototype sistem informasi Sistem Informasi Sekolah di Kabupaten atau Kota Serang Berbasis Web berdasarkan hasil perancangan analisa dan design sistem, yang akan dibuat menggunakan software-software desain web dan grafis, seperti Macromedia dreamweaver, PHP, Adobe Potoshop, Corel Draw dan lain-lain.

Tujuan Penelitian adalah menganalisis serta merancang sistem informasi sekolah berbasis web khususnya di SMA Negeri 2 Kota Serang guna memberikan 
suatu informasi tentang sekolah yang ada, baik di tingkat Kabupaten atau kota Serang mulai dari profil, lokasi sekolah, sarana dan prasaraana yang tersedia, kegiatan, pengajar dan prestasi sekolah serta semua hal yang dapat memberikan sedikit gambaran tentang suatu sekolahan.

\section{METODOLOGI PENELITIAN}

Kesulitan Orang tua untuk mengarahkan, memilih, dan menentukan anaknya ke sekolah SMA yang berkualitas dengan melihat profil sekolah, dan prestasi yang dicapai sekolah serta sumber daya pengajar disamping juga dengan memperhatikan nilai hasil belajar anaknya di Sekolah Menengah Pertama (SMP). Sedangkan informasi yang orang tua ketahui terbatas sebab informasi-informasi tersebut didapat dari cerita-cerita wali murid lain yang dirasa kurang akurat.

Untuk memberikan solusi dari permasalahan di atas dibuatlah suatu sistem informasi sekolah di Kabupaten atau Kota Serang dengan menggunakan media web dengan tujuan untuk memberikan informasi SMA yang akurat kepada masyarakat terutama orang tua calon siswa baru SMA.

\section{PerancanganSistem}

\section{Sistem Use Case}

Sistemusecase digunakan untuk memecah atau memilah proses bisnis ke dalam interaksi Berikut sistem use case pada sistem informasi sekolah : 
Jurnal Sistem Informasi dan Informatika (SIMIKA)

Vol.1 Nol tahun 2018

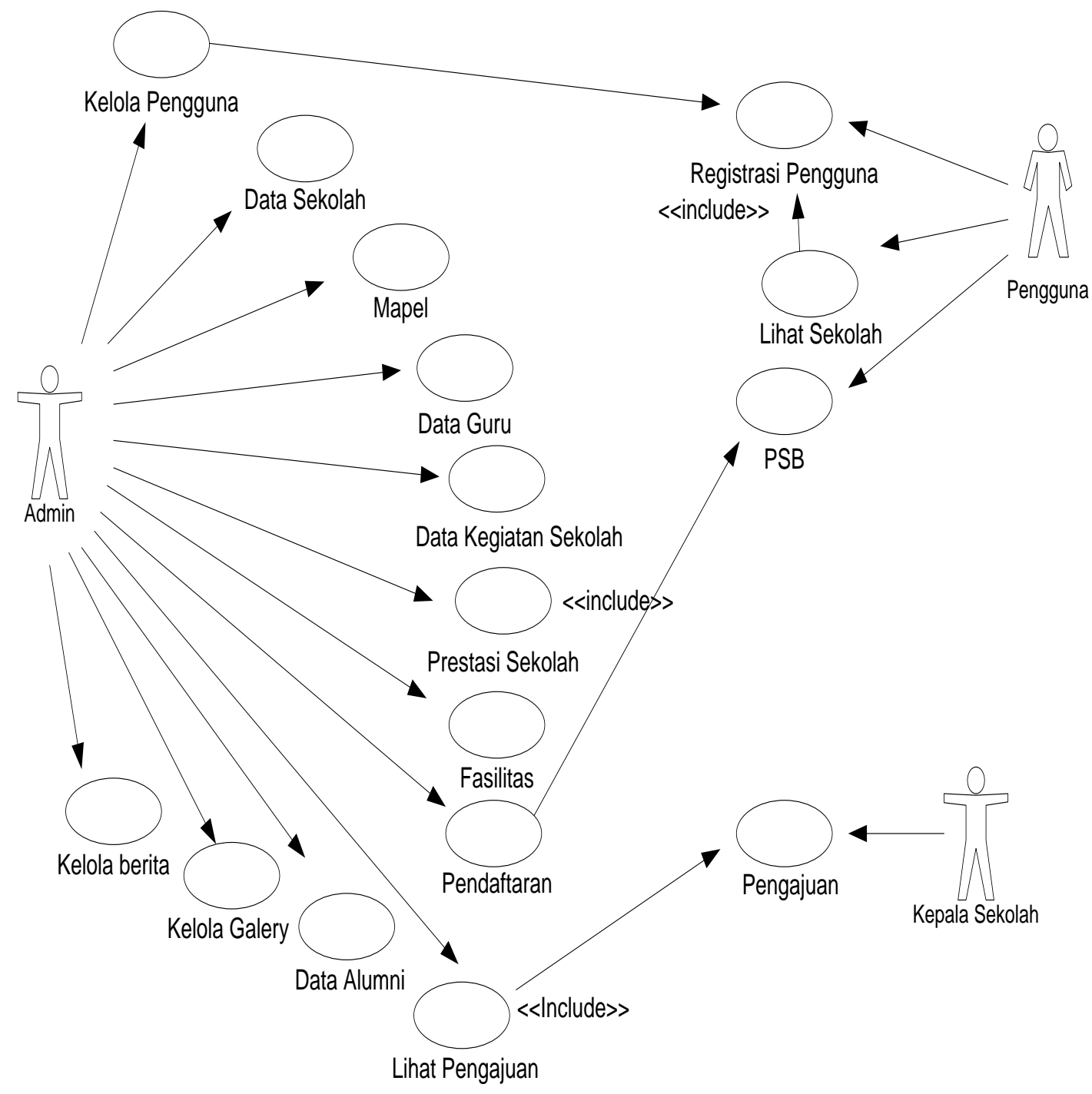

Gambar 1 Use Case Diagram 


\section{Class Diagram}

Class merupakan konstruksi atau komponen dari apa yang nantinya dibutuhkan dalam membuat suatu sistem. Berikut adalah class diagram dari sistem yang akan dibangun:

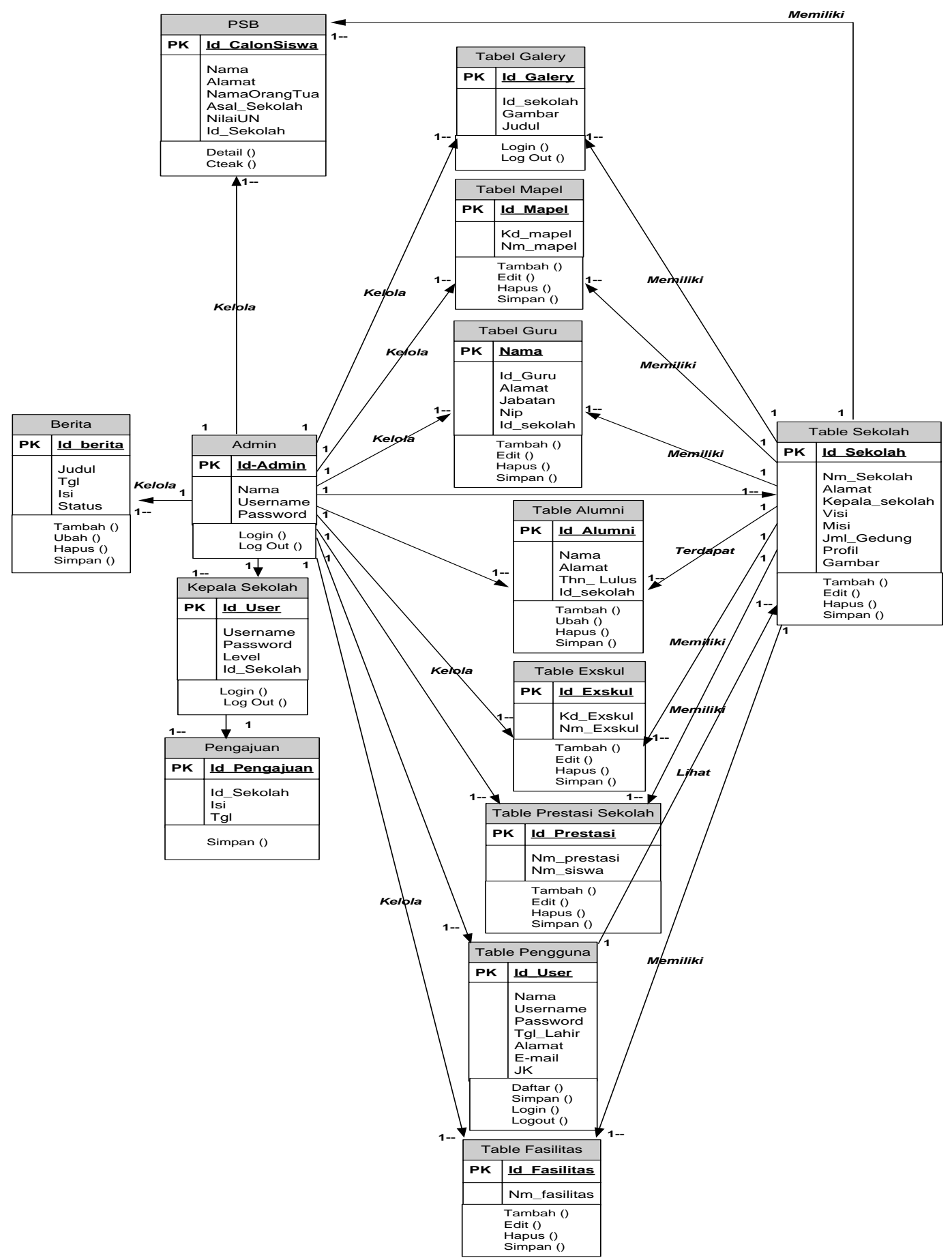

Gambar 2. Class Diagram 
Jurnal Sistem Informasi dan Informatika (SIMIKA)

Vol.1 Nol tahun 2018

\section{Sequence Diagram}

Sequence diagram kelola data menjelaskan secara detail urutan proses yang dilakukan dalam sistem untuk mencapai tujuan. Berikut ini adalah:

a. Sequence diagram kelola data pengguna

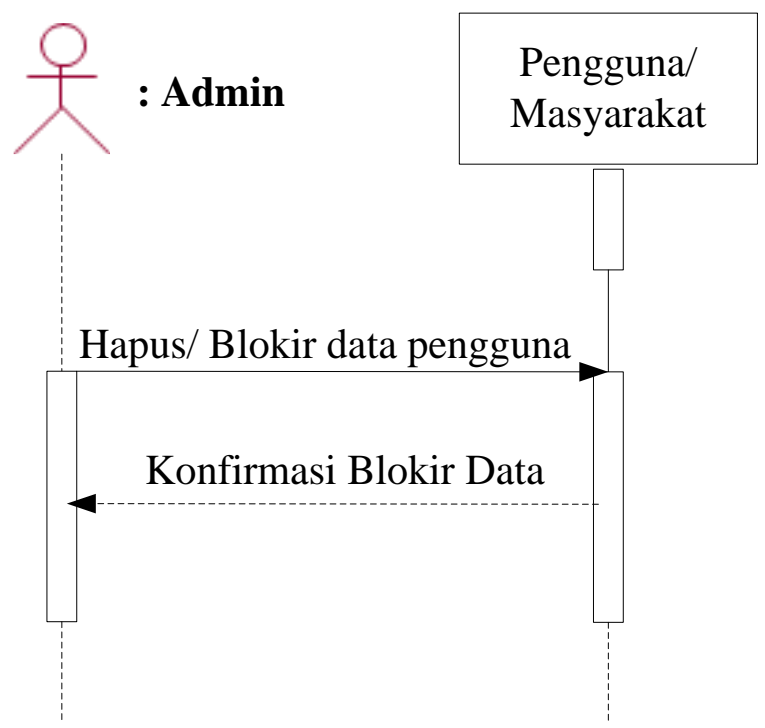

Gambar 3 Sequence diagram pengguna

b. Sequence diagram kelola data sekolah

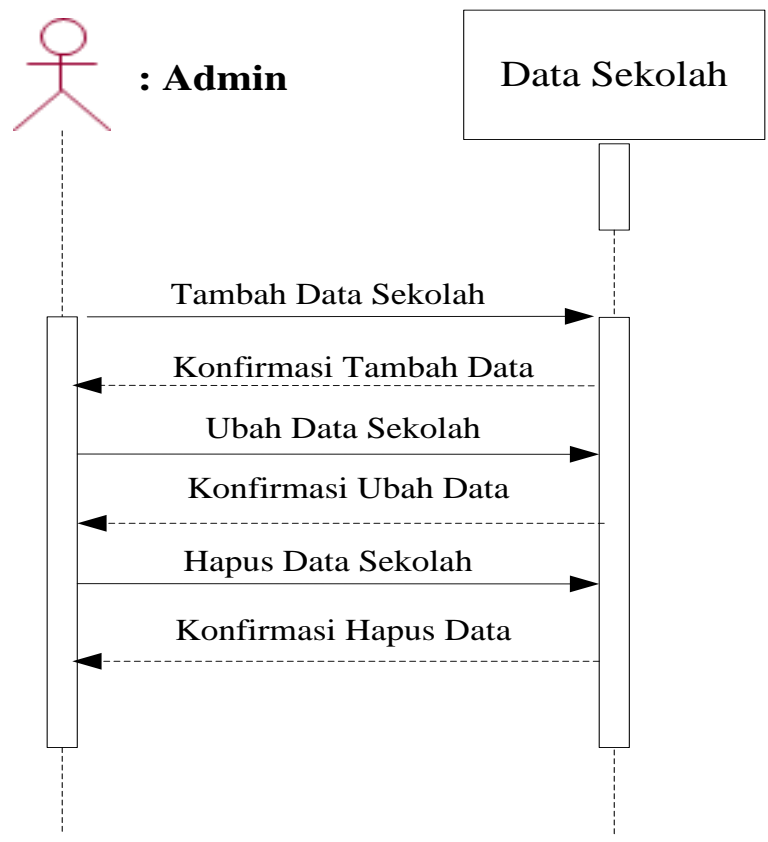

Gambar 4 Sequence diagram data sekolah 
Jurnal Sistem Informasi dan Informatika (SIMIKA)

Vol.1 Nol tahun 2018

c. Sequence diagram kelola data kegiatan sekolah. (Exskul)

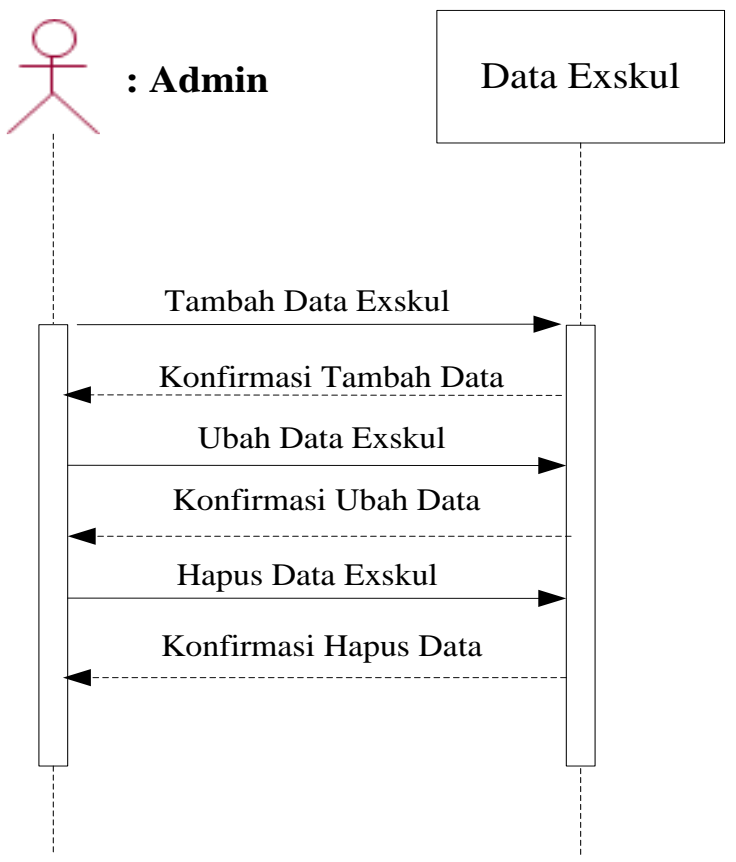

Gambar 5 Sequence diagram data kegiatan sekolah

d. Sequence diagram kelola data guru

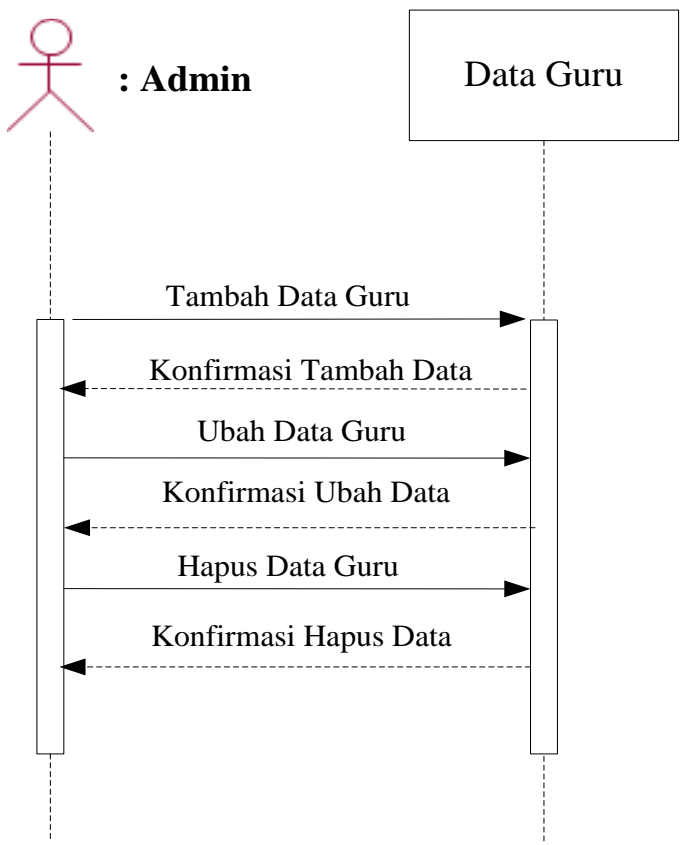

Gambar 6 Sequence diagram data guru 
Jurnal Sistem Informasi dan Informatika (SIMIKA)

Vol.1 Nol tahun 2018

\section{Activity Diagram}

Activity Diagram memodelkan alur kerja (workflow) sebuah proses bisnis dan urutan aktivitas dalam suatu proses. Activity Diagram yang ada di sistem yang penulis rancang antaralain

a. Activity diagram kelola data pengguna

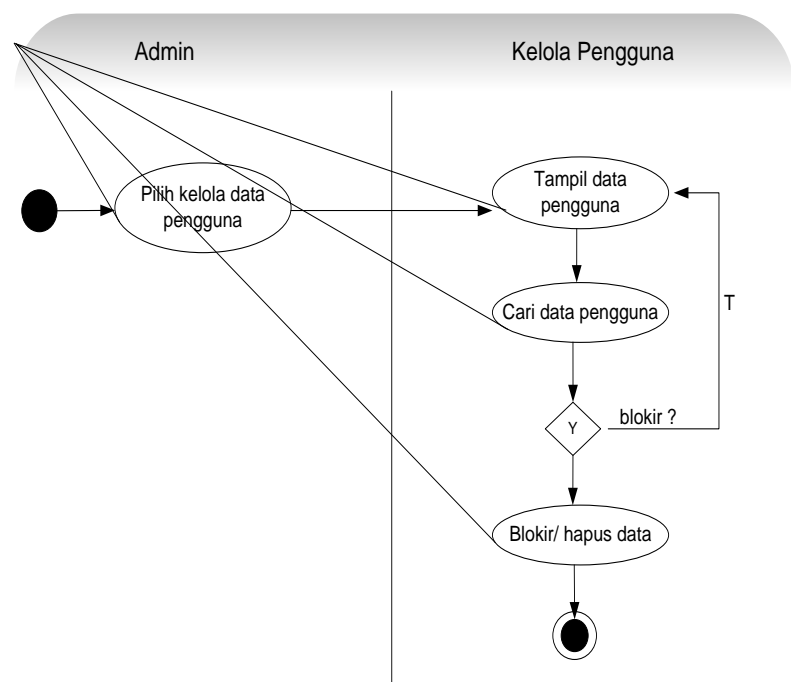

Gambar 7 Activity diagram kelola data pengguna

b. Activity diagram kelola data sekolah

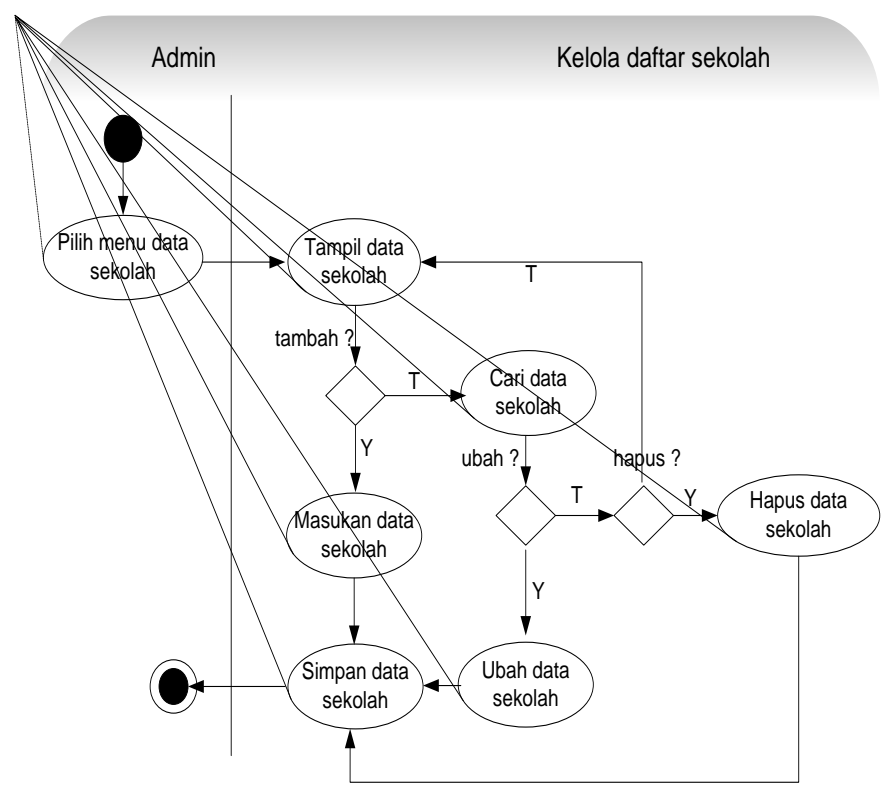

Gambar 8 Activity diagram kelola data sekolah 


\section{Relasi Tabel}

Untuk menggambarkan hubungan antar tabel perlu digunakan relasi tabel, dan berikut relasi antar tabel-tabel diatas :

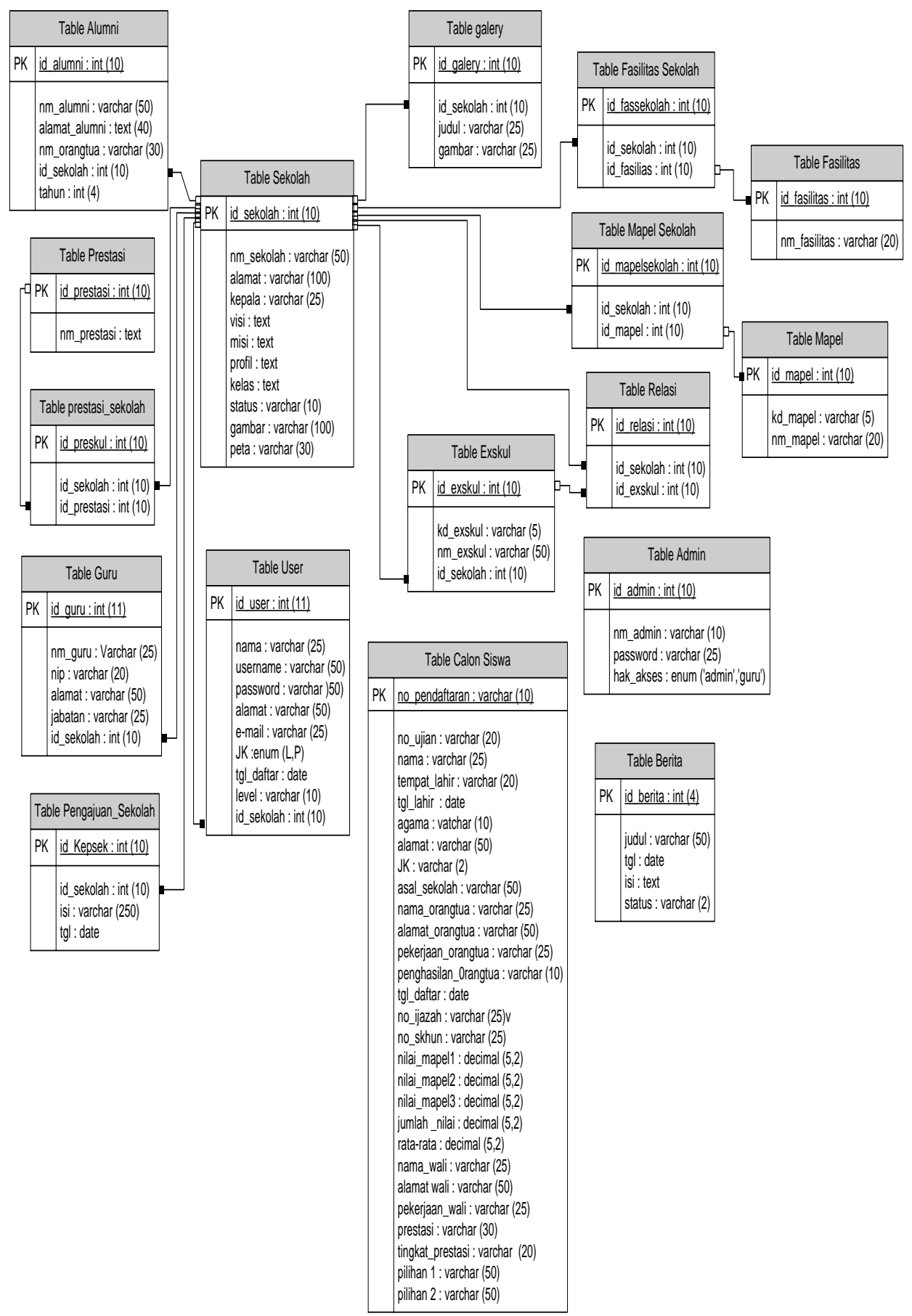

Gambar 9 Relasi Tabel 


\section{LITERATURE REVIEW}

Penelitianmengenai sistem informasi akademik sudah banyak dilakukan seperti pada penelitian yang dilakukan oleh Liatmaja (2013) dengan judul "Sistem Informasi Akademik Berbasis Web pada Lembaga Bimbingan Bimbingan Belajar Be ExcellentPacitan"yang mengembangkan suatu sistem pengolahan akademik meliputi informasi tentang nilai UTS atau UAS, nilai tryout, point serta jadwal akademik. Hasil penelitian ini adalah dapat mendukung kerja pengelola akademik ataupun sebagai acuan bagi pihak lembaga dalam melakukan perbaikan kinerja pelayanan terhadap siswa didik.

Adapun penelitian lainnya dilakukan oleh Utama (2011) dengan judul "Sistem Informasi Berbasis Web Jurusan Sistem Informasi Fakultas Ilmu Komputer Universitas Sriwijaya" penelitian ini merupakan suatu sistem yang memudahkan mahasiswa dalam melakukan kegiatan pengisian kartu rencana studi, dan mendapatkan informasi laporan nilai. Selain itu dengan berbasis web maka informasi data dapat diakses dengan waktu dan tempat yangtidak ditentukan. Pada sistem ini menu hanya dapat diakses oleh user tertentu yaitu siswa, dan administrator.

Padahasil penelitian ini telah dikembangkan sebuah sistem Informasi berbasis web dengan studi kasus pada jurusan sistem informasi fakultas ilmu komputer. Dimana dalam membangun sistem ini digunakan alat bantu pengembangan sistem yaitu Data Flow Diagran (DFD), Context Diagram, Entity Relationship Diagram (ERD), dan Flowchart serta dengan menggunakan bahasa pemrograman PHP dan $M y S Q L$ debagai databasenya.

Hasbi (2015) dalam jurnalnya melakukan penelitian dengan judul "Perancangan Sistem Informasi Akademik Pada SMK Negeri 2 Simbang Maros". Penelitian ini bertujuan untuk merancang Sistem Informasi Akademik di sekolah. Data diperoleh dengan teknik observasi dan dokumentasi. Penelitian ini merupakan jenis penelitian pengembangan yang mengembangkan suatu perangkat lunak (software development) dengan model pengembangan prototyping. Analisa data menggunakan analisa deskriftip.

Hasil penelitian menunjukan bahwa sistem ini memberikan kemudahan dalam pengaksesan ataupun manajemen data dan informasi akademik sehari-hari, seperti 
informasi data pelajaran, data guru, data siswa, data kelas, dan data nilai siswa. Dalam penelitian ini penulis akan mengimplementasikan sebuah sistem informasi akademik dengan bahasa pemrograman PHP dan framework Cadelgniter, dimana sistem ini dapat melakukan pengolahan nilai hingga pada penyajian raport, pengolahan data siswa, pembagian kelas, pembagian jadwal, pembagian guru kelas, serta manajemen silabus.

\section{KESIMPULAN}

Dari hasil analisis dan perancangan, serta implementasi dan pembahasan sebelumnya, penulis menarik kesimpulan sebagai berikut:

a. Dari analisis dan perancangan yang di buat penulis, sebagai dasar dalam pembuatan aplikasi berbasis web yang menyajikan informasi tentang sekolah khususnya di tingkat Kabupaten atau Kota Serang maka akan memudahkan bagi para oarang tua siswa dalam mencari informasi sekolah yang berkualitas dan diharapkan oleh para orang tua untuk mendaftarkan puta-putrinya.

b. Pengembangan dari aplikasi ini nantinya dapat digunakan untuk melakukan pendataan sekolah mulai dari profil sekolah, guru, mata pelajaran, ekstrakulikuler, fasilitas, alumni hingga prestasi yang dicapai oleh masing-masing sekolah yang ada di tingkat Kabupaten atau Kota Serang.

\section{SARAN}

Dengan telah dibangunnya sistem analisis dan perancangan sekolah berbasis web dalam pelaksanaan penelitian ini, maka penulis memberikan saran-saran sebagai berikut:

a. Sistem informasi berbasis web ini adalah salah satu fasilitas layanan informasi yang diharapkan bisa digunakan secara terus menerus oleh sekolah-sekolah lain yang ada di tingkat Kabupaten kota sesuai dengan kemajuan teknologi informasi dimana nantinya para orang tua siswa dapat mengetahui informasi sekolah secara langsung untuk mendaftarkan putra-putrinya.

b. Dalam pelaksanaan pembuatan sistem informasi berbasis web secara online, perlu diingatkan bahwa setiap sekolah nantinya harus melakukan pembaruan data-data 
sesuai dengan kenyataan dan perkembangan di sekolah tersebut.

c. Pada analisis dan perancangan sistem informasi berbasis web ini tentunya masih banyak kekurangan, untuk peneliti selanjutnya disarankan untuk menambah jumlah link, gambar, serta informasi terkait tentang sekolah yang akan di promosikan sesuai dengan data-data dan informasi yang diterapkan atau yang tengah berjalan pada sekolah tersebut.

\section{DAFTAR PUSTAKA}

Kadir. A., 2003, Pengenalan Sistem Informasi, Andi, Yogyakarta.

Ladjamudin. A.B.B, 2005, Analisis dan Desain Sistem Informasi, Graha Ilmu, Yogyakarta.

Nugroho. B., 2008, Latihan Membuat Aplikasi Web PHP dan MySQL dengan Dreamweaver, Gava Media, Jogyakarta.

Sait M.U., 2009, Perancangan Sistem Informasi Berbasis Web Pada SMKN 4 Surakarta, Skripsi, Teknik Industri, Universitas Muhammadiyah Surakarta, Surakarta.

Sholiq, 2010, Analisis dan Perancangan Berorientasi Objek, Muria Indah, Bandung.

Suhendar. A., dan Gunadi. H., 2002, Visual Modeling Menggunakan UML dan Rational Rose, Informatika, Bandung.

Sussanto. E., 2008, Perancangan Pelayanan Informasi Berbasis Web Pada Program Bimbingan Konseling di Sekolah, Skripsi, Ilmu Pendidikan, Universitas Lampung, Lampung.

Tohari, Hamim. 2014. Analisis Serta Perancangan Sistem Informasi Melalui Pendekatan UML.ANDI: Yogyakarta.

Sunyoto, Andi .2007. AJAX Membangun Web Dengan Teknologi Asychronouse JavaScript Dan XML. ANDI: Yogyakarta.

Tjiptono, Fandy. 2015. Strategi Pemasaran, Edisi 4, Yogyakarta: Andi. 